\title{
Quantitative autoradiographic localization of NMDA, quisqualate and $P C P$ receptors in the frog tectum
}

\author{
John W. McDonald ${ }^{1}$, Hollis T. Cline ${ }^{4}$, Martha Constantine-Paton ${ }^{4}$, William F. Maragos ${ }^{3}$, \\ Michael V. Johnston ${ }^{2,3}$ and Anne B. Young ${ }^{3}$ \\ ${ }^{4}$ Neuroscience and Medical Scientists Training Program, ${ }^{2}$ Departments of Pediatrics and ${ }^{3}$ Neurology, University of Michigan, Ann \\ Arbor, MI and ${ }^{4}$ Department of Biology, Yale University, New Haven, CT (U.S.A.)
}

(Accepted 15 November 1988)

Key words: Excitatory amino acid; N-Methyl-D-aspartic acid; Quisqualate; Phencyclidine; Autoradiography;

Visual plasticity; Frog; Tectum

\begin{abstract}
An organizing role for the $N$-methyl-D-aspartate (NMDA) receptor/channel has been suggested in the development of the retinotectal projection in Rana pipiens. The regional distributions of NMDA, phencyclidine (PCP) and quisqualic acid (QA) receptors were quantified using in vitro autoradiography in the tectum of normal and surgically produced 3-eyed juvenile frogs. NMDA and QA receptor binding was highest in the pretectum. Of the tectal layers, the superficial retinotectal synaptic zone, layer 9, had the highest amount of NMDA and QA receptor binding. Moderate binding was observed in layer 5, with little binding in the cellular layer 6 . No specific $\left[{ }^{3} \mathrm{H}\right] N-\left(1-[2\right.$-thienyl $]$ cyclohexyl) piperidine $\left(\left[{ }^{3} \mathrm{H}\right] \mathrm{TCP}\right)$ binding was observed in any of the tectal regions.
\end{abstract}

The development of the retinotectal projection in frogs involves a constant rearrangement of the retinotectal synaptic contacts in order to maintain a high-fidelity retinotopic map despite the mismatched growth patterns of the retina and optic tectum ${ }^{16}$. Studies using tetrodotoxin to block action potentials in the optic nerve demonstrate that the mechanisms for synaptic rearrangement or fine tuning require retinal ganglion cell (RGC) activity ${ }^{17}$. Recently, chronic treatment of the optic tectum with the $\mathrm{N}$-methyl-D-aspartate (NMDA) receptor antagonist aminophosphonovaleric acid (APV) has been shown to cause desegregation of the ocular dominance columns in surgically produced 3-eyed tadpoles ${ }^{3}$ and disruption of the refined retinotopic map in 2-eyed tadpoles ${ }^{4}$. Furthermore, treatment of optic tecta of 3-eyed tadpoles with NMDA itself appears to increase stripe segregation, as is evidenced by stripes with sharper borders ${ }^{3}$. These data suggest that the NMDA receptor, a subclass of glutamate receptors, is involved in the formation and maintenance of the topographic retinotectal projection in the frog.

Glutamate is a favored neurotransmitter in the RGCs of lower vertebrates. In goldfish, the broad scale glutamate receptor antagonists, kynurenate, $\gamma$-D-glutamylglycine and cis-2,3-piperidine dicarboxylate, block evoked field potentials in slices of optic tectum ${ }^{10}$. Similarly in the frog, evoked potentials recorded from the optic tectum following optic nerve stimulation are blocked reversibly by kynurenate ${ }^{6}$. Enucleation results in a decrease in high-affinity glutamate uptake in the optic tectum $^{18}$. Based on these data and the work summarized above, we hypothesized that binding sites for glutamate or other excitatory amino acids are located in the retinotectal synaptic zone of the optic tectum. Indeed, a recent study has shown the presence of glutamatergic ligand binding sites in the optic tectum of the goldfish ${ }^{8}$ although glutamate binding sites have not yet been demonstrated in the frog optic tectum.

Glutamate receptors are typically divided into

Correspondence: A.B. Young, University of Michigan, Neuroscience Laboratory Bldg., 1103 E. Huron, Ann Arbor, MI 48104, U.S.A. 
NMDA and non-NMDA subtypes according to their ability to be activated selectively by the ligand NMDA and blocked selectively by the antagonist APV (see ref. 14 for review). Non-NMDA glutamate receptor subtypes can be further divided into quisqualate (QA)- and kainate-sensitive binding sites, based on the selective affinities of these ligands. NMDA receptor activation is blocked noncompetitively by phencyclidine (PCP) receptor ligands including TCP and MK-801 (ref. 9) and NMDA and PCP receptors are colocalized in rats ${ }^{12}$. Therefore it is thought that the two receptors are part of the same receptor/channel complex ${ }^{14}$. Similarly, NMDA and non-NMDA receptors often appear colocalized in electrophysiological and anatomical studies ${ }^{7.11}$. We examined the regional distributions of NMDA- and quisqualate-sensitive $\left[{ }^{3} \mathrm{H}\right]$ glutamate binding sites and $\left[{ }^{3} \mathrm{H}\right] \mathrm{N}$ - $(1-[2-$ thienyl]cyclohexyl) piperidine $\left(\left[{ }^{3} \mathrm{H}\right] \mathrm{TCP}\right)$ binding sites within the tectum of normal and 3-eyed juvenile frog brains using quantitative autoradiography.

Normal $(n=4)$ and surgically produced 3-eyed ( $n$ = 3) juvenile Rana pipiens frogs (1-3 months postmetamorphosis) were anesthetized by immersion in $0.1 \%$ methanesulfonic acid (MS222, Sigma). Brains were rapidly removed and frozen immediately on dry ice. Radiolabelling of each receptor class was carried out on alternate $20 \mu \mathrm{m}$ coronal brain sections that were thaw-mounted onto gelatin-coated slides. NMDA- and QA-sensitive $\left[{ }^{3} \mathrm{H}\right]$ glutamate binding assays and $\left[{ }^{3} \mathrm{H}\right] \mathrm{TCP}$ binding assay were performed as described in the legend of Fig. 1.

Tissue sections were apposed to tritium-sensitive film (LKB Ultrofilm) for 35 days. A set of radioactive standards (ARC Tritium) calibrated against brain pastes with known amounts of tritium was co-exposed with each film. Quantitative analysis of the resulting autoradiograms was performed densitometrically using a microcomputer based video densitometer system (Imaging Research, St. Catherines, Ont.). Optical density values were converted to $\mathrm{pmol} / \mathrm{mg}$ protein using a computer-generated polynomial regression analysis which compared film densities produced by the tissue sections to those of radioactive standards ${ }^{15}$. Five or more autoradiographic sections were analyzed per animal and 10 readings were taken per area. Data represent specific binding $\left(90 \%\right.$ specific binding in $\left[{ }^{3} \mathrm{H}\right]$ glutamate
QUIS
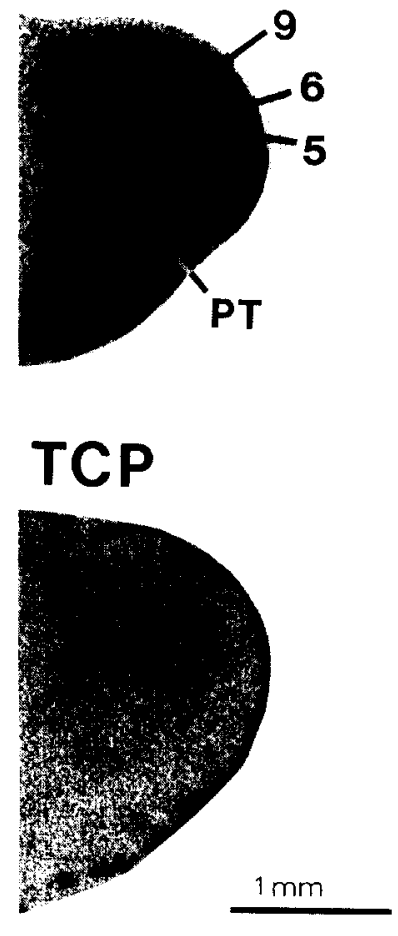

NISSL

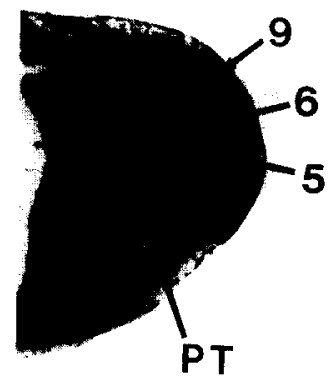

NMDA

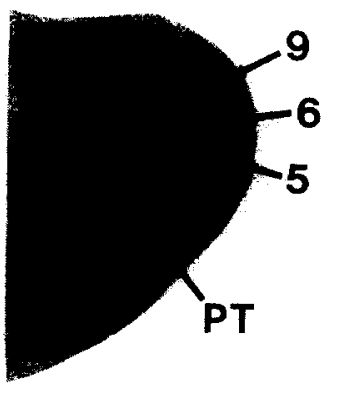

Fig. 1. Representative autoradiographic localization of $\left[{ }^{3} \mathrm{H} \mid \mathrm{TCP}\right.$ binding to PCP receptors and $\left[{ }^{3} \mathrm{H}\right]$ glutamate binding to quisqualate and NMDA receptors in the juvenile frog tectum. A tissue section stained for Nissl substance is included for comparison. For $\left[{ }^{3} \mathrm{H}\right] \mathrm{TCP}$ binding ${ }^{12}$, sections were preincubated for $30 \mathrm{~min}$ in ice-cold $50 \mathrm{mM}$ Tris-acetate, $\mathrm{pH} 7.4$ and then dried. Sections were then incubated for $45 \mathrm{~min}$ in the same ice-cold buffer with $1 \mathrm{mM}$ magnesium acetate and $30 \mathrm{nM}$ $\left[{ }^{3} \mathrm{H}\right] \mathrm{TCP}$ in the presence or absence of $20 \mu \mathrm{m}$ TCP. Magnesium (1 $\mathrm{mM}$ ) was added to the incubation medium, as this concentration has been shown to maximally increase $\left[{ }^{3} \mathrm{H}\right] \mathrm{TCP}$ binding $^{2,12}$. Rat brain sections were assayed in the same experiment to ensure that no problems had occurred in the $\left[{ }^{3} \mathrm{H}\right]$ TCP binding assay. Sections were then washed 3 times, 1 min each, in ice-cold buffer with $\mathrm{Mg}^{2+}$ and rapidly dried. No specific $\left[{ }^{3} \mathrm{H}\right]$ TCP binding was observed. The dense outer band of $\left[{ }^{3} \mathrm{H}\right] \mathrm{TCP}$ binding is an artifact of the embedding matrix. $\left[{ }^{3} \mathrm{H}\right]$ Glutamate binding was carried out under two different conditions that select for NMDA and quisqualate receptors ${ }^{7}$. For NMDA receptor binding, sections were preincubated in ice-cold Tris-acetate, $\mathrm{pH} 7.4$ and dried. Sections were then incubated in the same ice-cold buffer with $40 \mathrm{nM} \mathrm{L-}$ $\left[{ }^{3} \mathrm{H}\right]$ glutamate plus $2.5 \mu \mathrm{M}$ quisqualate in the presence or absence of $100 \mu \mathrm{M}$ glutamate. Sections were rapidly washed 3 times with $2 \mathrm{ml}$ of ice-cold buffer, followed by one rinse with a mixture of ice-cold glutaraldehyde and acetone (1:19 v/v) and then rapidly dried. Quisqualate receptor binding was carried out similarly except the buffer was $50 \mathrm{mM}$ Tris- $\mathrm{HCl}$ and the incubation buffer included $40 \mathrm{nM}\left[{ }^{3} \mathrm{H}\right]$ glutamate plus 2.5 $\mathrm{mM} \mathrm{CaCl}$ and $100 \mu \mathrm{M}$ NMDA. Under these conditions, QA-sensitive $\left[{ }^{3} \mathrm{H}\right]$ glutamate binding likely represents binding to postsynaptic neuronal QA receptors, rather than binding to 2-amino-4-phosphonobutyric acid (APB) receptors or chloridedriven vesicular uptake'. 


\section{TABLE I}

Specific binding of $\left[{ }^{3} H\right]$ glutamate to NMDA and quisqualate sites in juvenile frog brain

Values represent the mean \pm S.E.M. of 4 animals. Autoradiography and quantification of autoradiograms were carried out as described in Fig. 1. No specific $\left[{ }^{3} \mathrm{H}\right] \mathrm{TCP}$ binding was present in any areas studied.

\begin{tabular}{llc}
\hline Tectal areas & \multicolumn{2}{c}{ Ligand bound (pmollmg protein) } \\
\cline { 2 - 3 } & NMDA & Quisqualate \\
\hline Layer 9 & $0.51 \pm 0.03$ & $0.93 \pm 0.06$ \\
Layer 6 & $0.08 \pm 0.02$ & $0.28 \pm 0.01$ \\
Layer 5 & $0.18 \pm 0.03$ & $0.75 \pm 0.07$ \\
Pretectum & $0.84 \pm 0.10$ & $4.80 \pm 0.49$ \\
\hline
\end{tabular}

binding assays) and are expressed in $\mathrm{pmol} / \mathrm{mg}$ protein (mean \pm S.E.M.). $\left[{ }^{3} \mathrm{H}\right]$ Glutamate $(53 \mathrm{Ci} / \mathrm{mmol})$ and $\left[{ }^{3} \mathrm{H}\right] \mathrm{TCP}(47.6 \mathrm{Ci} / \mathrm{mmol})$ were obtained from New England Nuclear.

NMDA-sensitive and QA-sensitive $\left[{ }^{3} \mathrm{H}\right]$ glutamate receptor-specific binding was heterogeneously distributed throughout the normal frog tectum (Fig. 1; Table I). QA-sensitive glutamate binding was 45$88 \%$ higher in all tectal regions studied in comparison to NMDA-sensitive glutamate binding. In contrast, autoradiographic analysis of $\left[{ }^{3} \mathrm{H}\right] \mathrm{TCP}$ binding sites revealed no specific binding in any of the regions studied. NMDA and QA receptor binding was most concentrated in the pre-tectum (NMDA = $0.84 \pm 0.10 \mathrm{pmol} / \mathrm{mg}$ protein; $\mathrm{QA}=4.80 \pm 0.49$ $\mathrm{pmol} / \mathrm{mg}$ protein). Within the tectum, layer 9 , the retinotectal synaptic zone, had the highest density of binding $(\mathrm{NMDA}=0.51 \pm 0.03 \mathrm{pmol} / \mathrm{mg}$ protein; $\mathrm{QA}=0.93 \pm 0.06 \mathrm{pmol} / \mathrm{mg}$ protein). Cellular layer 6 had the least amount of binding (NMDA $=0.08 \pm$ $0.02 \mathrm{pmol} / \mathrm{mg}$ protein; $\mathrm{QA}=0.28 \pm 0.01 \mathrm{pmol} / \mathrm{mg}$ protein). Intermediate binding was found in the deep fiber layer $5(\mathrm{NMDA}=0.18 \pm 0.03 \mathrm{pmol} / \mathrm{mg}$ protein; $\mathrm{QA}=0.75 \pm 0.07 \mathrm{pmol} / \mathrm{mg}$ protein $)$. There were no differences in the amount of NMDA or QA receptor binding between normal and 3-eyed frogs (layer 9: $\mathrm{NMDA}=0.51 \pm 0.03$, normal vs $0.48 \pm 0.02$, 3 -eyed; $\mathrm{QA}=0.93 \pm 0.06$, normal vs $0.88 \pm 0.04$, 3 -eyed; independent two-tailed Student's $t$-test).

These results demonstrate that NMDA- and QA-sensitive glutamate binding is heterogeneously distributed within the frog tectum. The high density of NMDA and QA receptor binding in two RGC termination sites, the retinotectal synaptic zone (layer 9) of the optic tectum and the pretectum, is consistent with evidence that this pathway is glutamatergic. These data are also consistent with studies indicating that chronic NMDA receptor activation and blockade affect the plasticity of this system. The similar localizations of NMDA- and QA-sensitive binding sites suggests that a cooperative interaction of the different glutamate receptor subtypes may occur, as seen in other systems. For instance, activation of non-NMDA glutamate receptors may provide sufficient membrane depolarization to permit ion conductance through the voltage-sensitive NMDA receptor/channel ${ }^{11}$. The density of both NMDA and QA receptor binding in layer 9 is equivalent in normal and 3-eyed frogs. This may reflect a comparable number of synapses in the neuropil of normal and 3-eyed animals ${ }^{5}$.

No specific $\left[{ }^{3} \mathrm{H}\right] \mathrm{TCP}$ binding was observed in layer 9 or in any brain region examined in the juvenile frog. Similarly, no TCP binding sites were seen in goldfish brain ${ }^{8}$. These findings are in contrast to the identical distribution of NMDA receptors and PCP receptors in adult rats ${ }^{12}$. It may be that the PCP receptor is not expressed in early post-metamorphic frogs. Our preliminary studies in the developing rat suggest that expression of $\left[{ }^{3} \mathrm{H}\right] \mathrm{TCP}$ binding lags behind the expression of NMDA receptor binding in rat forebrain (manuscript in preparation). Furthermore, specific $\left[{ }^{3} \mathrm{H}\right] \mathrm{TCP}$ binding is present in adult frog brain homogenates and the non-competitive antagonist, ketamine, blocked NMDA-mediated electrophysiological responses in frog spinal cord ${ }^{13}$, ${ }^{19}$. In adult rat brain, low- and high-affinity $\left[{ }^{3} \mathrm{H}\right] \mathrm{TCP}$ binding sites are observed. Spinal cord, brainstem and cerebellum have predominantly low-affinity binding sites, whereas high-affinity sites predominate in forebrain. Except in cerebellum, NMDAreceptors appear co-localized with high-affinity sites. It is possible that low-affinity sites, not measured in the autoradiographic assay, predominate in juvenile brain. The relationship of low affinity sites to the functional NMDA receptor is unclear. It is possible, therefore, that the non-competitive NMDA receptor antagonists acting at the PCP receptor, in contrast to competitive antagonists, will not alter the development of ocular dominance column formation in 3-eyed frogs. 
We have previously shown that glutamate receptors, and the NMDA subtype in particular, are involved in the development of the retinotectal projection. Here we demonstrate a high density of glutamate receptor binding sites in a system widely recognized for its developmental plasticity. These data support our hypothesis that glutamate receptors, and the NMDA receptor/channel in particular, are involved in the fine tuning of the retinotectal

1 Cha, J.J., Greenamyre, J.T., Nielsen, E.O., Penney, J.B. and Young, A.B., Properties of quisqualate sensitive $\mathrm{L}-\left[{ }^{3} \mathrm{H}\right]$ glutamate binding sites in rat brain as determined by quantitative autoradiography, $J$. Neurochem., 51 (1988) 469-478.

2 Chu, D.C.M., Maragos, W.F., Penney, J.B. and Young, A.B., Magnesium ions increase binding affinity of dissociative anesthetic receptors but not of NMDA receptors in rat brain. In E.A. Cavalheiro, J. Lehmann and L. Turski (Eds.), Frontiers in Excitatory Amino Acid Research, Neurology and Neurobiology, Vol. 46, Liss, New York, 1988 , pp. $567-570$.

3 Cline, H.T., Debski, E.A. and Constantine-Paton, M., $\mathrm{N}$-methyl-D-aspartate receptor antagonist desegregates eye-specific stripes, Proc. Natl. Acad. Sci. U.S.A., 84 (1987) 4342-4345.

4 Cline, H.T. and Constantine-Paton, M., NMDA receptor antagonist, APV, disorganizes the retinotectal map, Soc. Neurosci. Abstr., 14 (1988) 674.

5 Constantine-Paton, M. and Norden, J.J., Synapse regulation in the developing visual system. In S.R. Hilfer and J.B. Sheffield (Eds.), Development of Order in the Visual System, Springer, New York, 1986, pp. 1-14.

6 Debski, E.A., Cline, H.T. and Constantine-Paton, M., Kynurenic acid blocks retinal-tectal transmission in Rana pipiens, Soc. Neurosci. Abstr., 13 (1987) 1691.

7 Greenamyre, J.T., Olson, J.M.M., Penney, J.B. and Young, A.B., Autoradiographic characterization of $\mathrm{N}$ methyl-D-aspartate-, quisqualate- and kainate-sensitive glutamate binding sites, J. Pharmacol. Exp. Ther., 233 (1985) 254-263.

8 Henley, J.M. and Oswald, R.E., Characterization and regional distribution of glutamatergic and cholinergic ligand binding sites in goldfish brain, $J$. Neurosci., 8 (1988) 2101-2107.

9 Kemp, J.A., Foster, A.C. and Wong, E.H.F., Noncompetitive antagonists of excitatory amino acid receptors, projection. The data also support the role of excitatory amino acids neurotransmitters in the retinotectal projection of the frog.

Supported by USPHS Grants 1P01NS19613 (M.V.J., A.B.Y.) MSTP Grant 5 T32 6M07863-07 J.W.M, and by NIH Grants E405818 (H.T.C.), E406039 (M.C.P.).

Trends Neurosci., 10 (1987) 294-298.

10 Langden, R.B. and Freeman, J.A., Antagonists of glutaminergic neurotransmission block retino-tectal transmission in gold fish, Brain Research, 398 (1986) 169-174.

11 MacDermott, A.B. and Dale, N., Receptors, ion channels and synaptic potentials underlying the integrative actions of excitatory amino acids, Trends Neurosci., 10 (1987) 280284.

12 Maragos, W.F., Penney, J.B. and Young, A.B., Anatomic correlation of NMDA and 3H-TCP-labeled receptors in rat brain, J. Neurosci., 8 (1988) 493-501.

13 Martin, D. and Lodge, D., Ketamine acts as a noncompetitive $N$-methyl-D-aspartate antagonist on frog spinal cord in vitro, Neuropharmacology, 24 (1985) 999-1003.

14 Mayer, M.L. and Westbrook, G.L., The physiology of excitatory amino acids in the vertebrate central nervous system, Prog. Neurobiol., 28 (1987) 197-276.

15 Pan, H.S., Frey, K.A., Young, A.B. and Penney, J.B., Changes in $\left[{ }^{3} \mathrm{H}\right]$ muscimol binding in substantia nigra, entopeduncular nucleus, globus pallidus, and thalamus after striatal lesions as demonstrated by quantitative receptor autoradiography, J. Neurosci., 3 1189-1198.

16 Reh, T.A. and Constantine-Paton, M., Retinal ganglion cell terminals change their projection sites during larval development of Rana pipiens, J. Neurosci., 4 (1984) 442-457.

17 Reh, T.A. and Constantine-Paton, M., Eye-specific segregation requires neural activity in three-eyed Rana pipiens, J. Neurosci., 5 (1985) 1132-1143.

18 Roberts, P.J. and Yates, R.A., Tectal deafferentation in the frog: selective loss of L-glutamate and gamma-aminobutyrate, Neuroscience, 1 (1976) 371-374.

19 Vu, T.H., Weissman, A.D. and London, E.D., Phylogenetic distribution of haloperidol-sensitive sigma and phencyclidine binding sites in the nervous system, Soc. Neurosci. Abstr., 13 (1987) 1703. 